\title{
Scanning electron microscopy of the coccidian parasite Cryptosporidium sp. from cichlic fishes
}

\section{Paperna}

Department of Animal Sciences, Faculty of Agriculture, Hebrew University of Jerusalem, Rehovot 76-100, Israel

\begin{abstract}
A scanning electron microscopic study of Cryptosporidium sp. from the stomach of the cichlid fish Oreochromis aurea from Lake Kinnereth, Israel, revealed the existence of regularly spaced projections on their parasitophorous envelope. In young specimens the envelope was not complete leaving a hollow at their apex.
\end{abstract}

Landsberg \& Paperna (1986) authored a transmission electron microscopic (TEM) study of the coccidian Cryptosporidium sp. which they found attached to the microvillar zone of the stomach epithelium of cultured hybrids of the cichlids Oreochromis aureus $\times 0$. niloticus. Subsequently, Cryptosporidium sp. infection was found in fry (10 to $17 \mathrm{~mm}$ long) of $O$. aureus collected from shallow pools fringing the northwestern shores of Lake Kinnereth, Israel. Isolated infected stomachs from 2 fish were processed for scanning electron microscopy (SEM): fixed in Karnowski's fixative for $24 \mathrm{~h}$ at $4^{\circ} \mathrm{C}$, rinsed 3 times in cacodylate buffer (0.1 M, pH 7.4), dehydrated in an ascending series of alcohols, gradually infiltrated with amyl-acetate, critical-point-dried from liquid carbon dioxide in a polaron E 3000, and sputter-coated with gold in a polaron E 5150. Specimens were examined and photographed using a Jeol JSM 35C SEM.

Results are presented in Figs. 1 to 6 , and $8 \&$ 9. SEM micrographs confirm TEM findings of Landsberg \& Paperna (1986) of regular projections on the parasitophorous envelope which encloses the parasite (Fig. 7). This envelope derives from the microvillar outer wall of the host cell (Pohlentz et al. 1978). It was suggested that these projections were rudiments of host cell microvilli. Such projections were not seen in any of the species of Cryptosporidium from mammalian, avian or reptilian hosts thus far studied by TEM or SEM (Brownstein et al. 1977. Pearson \& Logan 1983, Motoveto et al. 1984, O'Donoghue 1985, Tzipori 1985). Fusion of microvilli adjacent to the parasite into the parasitophorous membrane, as demonstrated in some mammalian Cryptosporidium (Inman \& Takeuchi
1979), was not observed in the studied SEM material. A distinct collar occurs in the SEM observed specimens (Fig. 2 \& 3) in proximity to their attachment end; this may correspond to the TEM observed zone limited between the 2 microfibrillar bands (Landsberg \& Paperna 1986). Projections were numerous in the smaller specimens ( 1.3 to $2.0 \mu \mathrm{m}$ high, Figs. 1 to 3,8 \& 9), and were diminishing in the larger $(2.0$ to $3.5 \mu \mathrm{m}$ high, up to $5.0 \mu \mathrm{m}$ wide; Figs. $5 \& 6$ ), presumably maturing, meronts and gamonts. TEM electron micrographs (Landsberg \& Paperna 1986) reveal, however, the presence of projections also in differentiated meronts and gamonts.

In some young parasites the formation of the parasitophorous envelope appears to be not yet completed, leaving a hollow at the apical end (Fig. 9). A ruptured specimen (Fig. 8) revealed the thickness of the parasitophoroused envelope (about $6 \mathrm{~nm}$ ).

Acknowledgements. I thank Mrs Naomi Bahat for technical assistance. This study was supported by a grant from the Council for Scientific and Industrial Research, Republic of South Africa

\section{LITERATURE CITED}

Brownstein, D. G., Strandberg, J. D., Montali, R. J., Bush, M. Fortner, J. (1977). Cryptosporidium in snakes with hypertrophic gastritis. Vet. Pathol. 14: 606-617

Inman, L. R., Takeuchi, A. (1979). Spontaneous Cryptosporidiosis in adult female rabbit. Vet. Pathol. 16: 89-95

Landsberg, J. H., Paperna, I. (1986). Ultrastructural study of the coccidian Cryptosporidium sp. from stomachs of juvenile cichlid fish. Dis. aquat. Org. 2: 13-20

Motoveto, J. A. Landsverk, T., Amaya-Posada G. (1984). Cryptosporidiosis in Tanzanian goat kids: scanning and transmission electron microscopic observations. Acta vet. scand. 25: $322-326$

O'Donoghue, P. J. (1985). Cryptosporidium infections in man animals birds and fish. Aust. Vet. J. 62: 253-258

Pearson, G. R., Logan, E. F. (1983). Scanning and transmission 

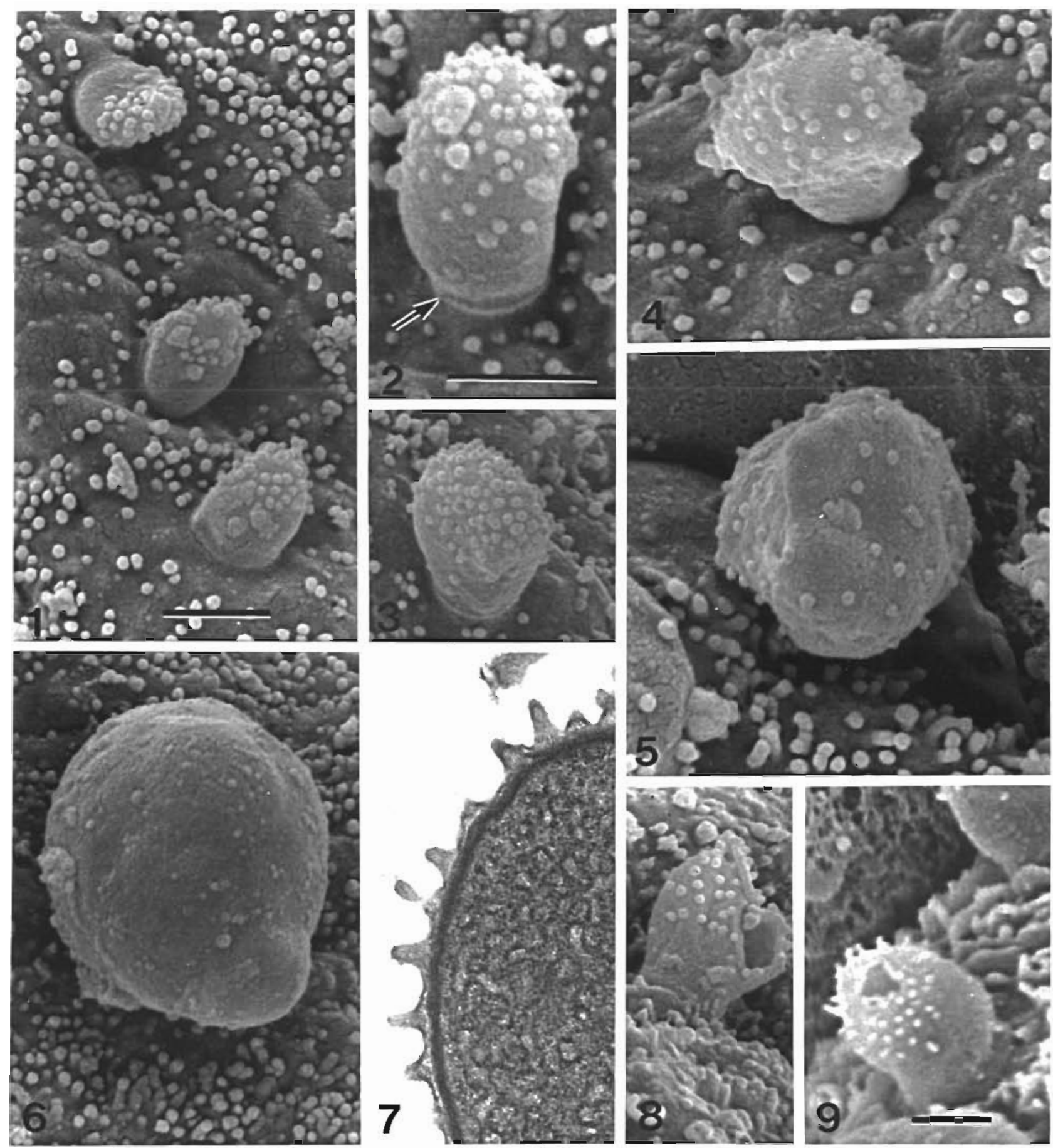

Figs. 1 to 9. Cryptosporidium sp. from stomach of Oreochromis aurea. Figs. 1 to 4. Scanning electron micrographs (SEM) of young specimens; arrow collar near attachment end. Figs. $5 \& 6$ SEM of later developmental stages. Fig. 7. Transmission electron micrograph (TEM) of a meront stage, $\times 48000$ (for methods see Landsberg \& Paperna 1986). Fig. 8. SEM of ruptured specimen.

Fig. 9. SEM of young specimen with hollowed apical end. Bar $=1 \mu \mathrm{m}$; same scale for Figs. $1,3,6 \& 8$ and for Figs. 2,4 \& 5

electron microscopic observations on the host-parasite relationship in intestinal cryptosporidiosis of neonatal calves. Res. Vet Sci. 34: 149-154

Pohlentz, J., Bemrick, W. J., Moon, H.W., Cheville, N. F.

(1978). Bovine Cryptosporidiosis: a transmission and scan- ning electron microscopic study of some stages in the life cycle and of the host-parasite relationship. Vet. Pathol. 15: $417-427$

Tzipori, S. (1985). Cryptosporidium: notes on epidemiology and pathogenesis. Parasitology Today 6: 159-165 